\title{
STRATEGI PENGELOLAAN UNTUK MENINGKATKAN KEPUASAN PELANGGAN WISATA KULINER PADA WARUNG SATE KAMBING MUDA "MASYHUDI" DI DESA BLOTONGAN SALATIGA
}

\author{
Oleh: \\ Samtono \\ STIEPARI Semarang
}

\begin{abstract}
Abstrak
Makanan khas jawa sebagai warisan leluhur sampai saat ini masih menjadi buruan para lelaki paruh baya karena dipercaya sebagai menu yang menambah stamina bagi pria, ribuan orang tiap bulan selalu menikmati sate kambing muda di sentra kuliner warung sate kambing di Desa Blotongan Salatiga, Saat ini pengembangan destinasi wisata kuliner merupakan jalur strategis penyangga ekonomi nasional lewat Usaha Mikro, Kecil, dan Menengah (UMKM).

Adapun tujuan kegiatan penelitian ini adalah: a.Untuk mendiskripsikan dan menjelaskan sikap dan perilaku pelaku usaha wisata kuliner warung sate kambing muda "Masyhudi". b. Untuk mendeskripsikan dan menjelaskan strategi yang ditempuh untuk meningkatkan kepuasan pelanggan wisata kuliner warung sate kambing muda "Masyhudi"; c.Untuk mendiskripsikan dan menjelaskan strategi yang ditempuh untuk meningkatkan omzet pendapatan warung sate kambing muda "Masyhudi".

Penelitian dilakukan dengan pendekatan diskriptif kualitatif dengan metode pengumpulan data, depth Interview, swot analisis dan observasi baik secara langsung maupun tidak langsung terhadap beberapa informan atau nara sumber yang terseleksi atau terpilih khususnya para karyawan, pelanggan, dan pemilik warung makan.

Adapun hasil penelitian yang diperoleh melalui Analisis SWOT dilakukan berdasarkan teknik EFAS dan IFAS, kemudian dihitung dengan perhitungan AFE dan IFE yaitu analisis faktor eksternal dan fakor internal menunjukkan para konsumen merasa puas akan pelayanan yang diberikan oleh warung sate kambing muda Masyhudi. Posisi warung makan sate kambing muda Masyhudi di Desa Blotongan Salatiga berdasarkan diagram kortesius SWOT berada di kwadran I, artinya kuat dan berpeluang. Rekomendasinya adalah strategi yang diberikan progresif. Dalam rangka meningkatkan omzet pendapatan usahanya maka dapat menambah varians atau jenis menu yang disajikan konsumen serta mengembangkan usahanya dengan membuka anak perusahaan.
\end{abstract}

\section{Kata Kunci : UMKM, Wisata Kuliner, Menu Varians}




\section{PENDAHULUAN}

Usaha Mikro, Kecil, dan Menengah, ( UMKM ) mempunyai peranan stategis dalam pembangunan ekonomi nasional. UMKM berperan dalam pertumbuhan ekonomi dan penyerapan tenaga kerja. Selain itu juga berperan dalam pendistribusian hasil-hasil pembangunan. Keberadaan sektor Usaha Mikro, Kecil,dan Menengah, bukan hanya tempat penampungan sementara bagi para pekerja yang belum masuk ke sektor formal, tetapi sebagian besar berlokasi di pedesaan.

Suryana ( 2014 ) menyebutkan ada empat alasan yang menjelaskan posisi strategis UMKM di Indonesia. Pertama, UMKM tidak memerlukan modal yang besar sebagaimana perusahaan besar sehingga pembentukan perusahaan ini relatif mudah tidak sesulit usaha besar. Kedua, tenaga kerja yang diperlukan tidak menuntut pendidikan formal tertentu. Ketiga, sebagian besar berlokasi dipedesaan dan tidak memerlukan infrastruktur sebagaimana perusahaan besar. Keempat, UMKM terbukti memiliki ketahanan yang kuat ketika Indonesia dilanda krisis ekonomi. Kementrian Koperasi dan UMKM (2012) menyebutkan usaha mikro, kecil menengah yang berkembang saat ini terbagi menjadi beberapa kategori, yaitu pertanian, peternakan, perikanan, kehutanan, air bersih, perdagangan, hotel, restoran/rumah makan, jasa-jasa swasta, dan industri pengolahan salah satunya mencakup industri kreatif. Pemerintah mulai memperhatikan pertumbuhan ekonomi kreatif sebagai alternatif roda penggerak ekonomi yang akan terus berputar, industri dan ekonomi kreatif meliputi subsektor yaitu industri makanan khas daerah Salatiga seperti Warung Sate Kambing Muda di Desa Blotongan Salatiga yang selama ini menjadi pusatnya wisata kuliner sate kambing muda, di Desa Blotongan ada 14 warung sate kambing muda yang menjajakan makanan khas jawa dan terkenal sejak jaman kolonial dan sampai saat ini sangat digemari oleh para kaum lelaki khususnya yang paruh baya. Mengingat menu sate kambing muda sangat dipercaya sebagai menu yang kaya akan protein dan nutrisi yang bisa membuat stamina seorang laki-laki menjadi hebat dan kuat. Sesuai kebijakan dari pemerintah lewat Kementrian Pariwisata unutk mensukseskan kunjungan wisata mancanegara sebanyak 20 juta wisatawan di tahun 2019, lewat slogan nasional Wonderful Indonesia (Kemenpar, 2019) hal ini perlu didukung berbagai 
infrastruktur dan prasarana yang lain seperti kesiapan hotel dan ketersediaan wisata kuliner yang representatif yang memenuhi Standard Halal Tourism. Pusat wisata kuliner sate kambing muda di Blotongan Salatiga menyerap tenaga kerja sekitar 250 orang, sehingga keberadaannya sangat membantu kehidupan masyarakat yang bekerja di rumah makan sate kambing muda tersebut.

Dinamika para pelaku usaha kecil yang selama ini cukup kondusif dan dinamis akhir-akhir ini sangat dirasakan para pengelola warung makan sering terjadi pasang surut setelah dibukanya jalan Toll Sesi Bawen - Salatiga sehingga para pelaku mengalami pasang surut omset penjualannya, dulu penggemar sate kambing muda mulai dari Jakarta, Bogor, Bandung, sampai Surabaya selalu mampir ke warung makan sate kambing muda, bahkan pelanggan fanatik mulai dari Singapura, Malaysia, bahkan Thailand pun datang hanya ingin menikmati sate kambing muda yang khas Blotongan Salatiga.

Mengingat Kota Salatiga sudah memiliki Peraturan Daerah Nomor : 10 Tahun 1993 dan Peraturan Daerah Nomor: 5 Tahun 1996. yang di dalamnya memuat Salatiga sebagai Kota Pendidikan, Kota Olah Raga, dan sebagai Kota Transit yang disebut sebagai “ Tri Fungsi Kota Salatiga”. Disamping itu Salatiga juga sudah memiliki produk-produk unggulan seperti Abon sapi, Dendeng, Enting-enting, Gula kacang, Bandeng asap, dan sebagainya yang sudah mencapai pasaran seluruh nusantara, bahkan seperti abon sapi dan dendeng sapi sudah menjadi produk unggulan khas daerah dan menjadi komoditi ekspor.

Kota Salatiga memiliki posisi yang sangat strategis untuk keperluan pengembangan ekonomi kreatif, khususnya di Desa Blotongan karena menempati jalan raya Semarang Solo, dan mendapat predikat sebagai kota transit, mengingat banyak masyarakat selama ini yang menempuh perjalanan dari Solo ke Semarang menyempatkan mampir untuk menikmati kuliner sate kambing muda di Desa Blotongan Salatiga, atau sebaliknya yang dari Semarang menuju ke Solo.

Kegiatan Penelitian yang akan dilaksanakan difokuskan pada Strategi Peningkatan Kepuasan Pelanggan Wisata Kuliner Warung sate kambing muda "Masyhudi" di Desa Blotongan Salatiga 


\section{Rumusan Masalah}

1. Bagaimana sikap dan perilaku pelaku usaha wisata kuliner warung sate kambing muda "Masyhudi" di Desa Blotongan Salatiga untuk mengembangkan usahanya?

2. Bagaimana stategi yang yang ditempuh pelaku uasaha wisata kuliner untuk meningkatkan kepuasan pelanggan wisata kuliner warung sate kambing muda "Masyhudi"di Desa Blotongan Salatiga?

3. Bagaimana strategi untuk meningkatkan omset pendapatan dalam pengembangan usaha wisata kuliner warung sate kambing muda "Masyhudi" di Desa Blotongan Salatiga?

\section{Tujuan dan Manfaat Penelitian}

Kegiatan penelitian bermaksud mengungkap sikap dan perilaku bagi pelaku usaha wisata kuliner warung sate kambing muda "Masyhudi" dalam meningkatkan kepuasan pelanggannya. Atas dasar beberapa pertanyaan penelitian tersebut diatas, maka tujuan penelitian adalah sebagai berikut:

1. Untuk mendiskripsikan dan menjelaskan sikap dan perilaku pelaku usaha wisata kuliner warung sate kambing muda "Masyhudi" untuk meningkatkan usahanya di Desa Blotongan Salatiga

2. Untuk mendeskripsikan dan menjelaskan strategi yang ditempuh untuk meningkatkan kepuasan pelanggan wisata kuliner warung sate kambing muda "Masyhudi” di Desa Blotongan Salatiga.

3. Untuk mendiskripsikan dan menjelaskan strategi yang ditempuh untuk meningkatkan omzet pendapatan warung sate kambing muda "Masyhudi" di Desa Blotongan Salatiga.

\section{PAPARAN TEORITIS}

\section{Teori Sikap dan Perilaku}

a. Sikap

Istilah sikap ( attitude ) pertama kali digunakan pada tahun 1862 oleh seorang ahli bernama Hebert Spencer yang pada waktu itu diartikan sebagai status mental seseorang, selanjutnya Azwar (2013) menjelaskan istilah sikap sebagai respons untuk menggambarkan kesiapan mengahadapi stimulus yang datang secara tiba-tiba, dimaksudkan sikap 
tidak hanya aspek mental saja melaikan juga mencakup respons fisik. Sikap disini dikandung maksud para pelaku usaha wisata kuliner warungmakan sate kambing muda di Desa Blotongan Salatiga.

\section{b. Perilaku Manusia}

Perilaku atau aktivitas-aktivitas individu secara luas adalah perilaku yang menampak (ober behavior) dan perilaku yang tidak Nampak (inner behavior) dan sikap selalu dikaitkan dengan perilaku manusia dalam batas-batas kewajaran dan kemakmuran yang merupakan respons atau reaksi terhadap stimulus lingkungan sosial ( Azwar, 2013). Salah satu reaksi perilaku manusia yang menarik adalah sifat deferensial, maksudnya satu stimulus dapat menimbulkan beberapa stimulus yang lain yang berbeda, dan stimulus yang berbeda-beda dapat menimbulkan respon yang sama.

\section{c. Pembentukan Perilaku}

Perilaku manusia sebagian besar iyalah berupa perilaku yang dibentuk, perilaku yang dipelajari, berkaitan dengan hal tersebut maka salah satu persoalan adalah bagaimana membentuk perilaku seperti yang diharapkan. Adapun pembentukan perilaku ada beberapa cara atau bentuk, yakni sebagai berikut : pertama pembentukan perilaku dengan cara kondisioning atau pembiasaan, kedua, pembentukan perilaku dengan insight atau pengertian dan pemahaman, ketiga, pembentukan perilaku dengan model, Bandura dalam Samtono ( 2009 ), adapun model yang dikembangkan Bandura sebagai,

\section{Gambar 1}

\section{Pembentukan Perilaku Model Bandura}

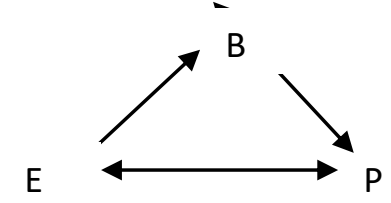

$$
\begin{aligned}
& \mathrm{B}=\text { Behavior } \\
& \mathrm{E}=\text { Environment } \\
& \mathrm{P}=\text { Person }
\end{aligned}
$$


Dari model Bandura di ilustrasikan bahwa perilaku, lingkungan dan individu itu sendiri saling berinteraksi satu dengan yang lain. Ini berarti bahwa perilaku individu dapat mempengaruhi individu itu sendiri, disamping prilaku juga berpengaruh pada lingkungan, demikian pula lingkungan dapat mempengaruhi individu dan sebaliknya. Dari ilustrasi Bandura tersebut diatas, berimplikasi pada pengembangan wisata kuliner warung sate kambing muda di Desa Blotongan Salatiga, merupakan hasil proses interaksi antara individu dengan individu, dan individu dengan lingkungan masyarakat pelaku usaha wisata kuliner sate kambing muda, yang dari waktu ke waktu semakin bertambah para pelaku usaha wisata kuliner warung makan disekeliling rumah makan sate kambing muda seperti sate ayam, sate sapi, soto babat, soto ayam, dan bermunculan varians warung makan di Desa Blotongan Salatiga .

Usaha Mikro, Kecil, dan Menengah ( UMKM )

Usaha Mikro, Kecil, dan Menengah memiliki definisi yang berbeda pada setiap literature menurut beberapa intansi atau lembaga bahkan undang-undang. Sesuai dengan Undang-Undang Republik Indonesia Nomor 20 tahun 2008 tentang Usaha Mikro, Kecil, dan Menegah (UMKM) didefinisikan sebagai berikut:

a. Usaha Mikro adalah usaha produktif milik orang perorangan dan atau badan usaha perorangan yang memenuhi kriteria usaha mikro sebagaimana diatur dalam Undang-Undang

b. Usaha Kecil adalah usaha ekonomi produktif yang berdiri sendiri, yang dilakukan oleh perorangan atau badan usaha yang bukan milik anak perusahaan atau bukan cabang perusahaan yang dimiliki, dikuasai, atau menjadi bagian baik langsung maupun maupun tidak langsung dari usaha menengah atau usaha besar yang memenuhi kriteria Usaha Kecil sebagaimana dimaksud dalam Undang-Undang.

c. Usaha Menengah adalah usaha ekonomi produktif yang berdiri sendiri, yang dilakukan oleh orang perorangan atau Badan Usaha yang bukan merupakan anak perusahaan, atau cabang anak perusahaan yang dimiliki, dikuasai, atau menjadi bagian baik langsung maupun tidak langsung dengan Usaha Kecil atau Usaha Besar dengan jumlah kekayaan bersih 
atau hasil penjualan tahunan sebagaimana diatur dalam Undang-Undang Nomor 20 Tahun 2008 pasal 6.

\section{Pariwisata}

Pariwisata memiliki definisi yang berbeda-beda karena konsepnya yang sangat multidimensional. Berdasarkan persfektifnya masing-masing sesuai dengan tujuan yang ingin dicapai, para praktisi dan ahli juga mendefinisikan pariwisata secara berbeda-beda. Undang-Undang Republik Indonesia Nomor 10 Tahun 2009 menyebutkan bahwa keadaan alam, flora, dan fauna, sebagai karunia Tuhan Yang Maha Esa serta peninggalan sejarah dan purbakala, seni, dan budaya yang dimiliki bangsa Indonesia merupakan modal sumber daya dan modal pembangunan kepariwisataanuntuk meningkatkan kemakmuran dan kesejahteraan rakyat sebagai yang tercantum dalam Pancasila dan Undang-Undang Dasar Negara Republik Indonesia Tahun 1945. Selanjutnya Wali dalam Soleha (2015) menjelaskan pariwisatasebagai rangkaian aktivitas berupa aktivitas perpindahan orang, untuk sementarawaktu ke suatu tujuan di luar tempat tinggal maupun tempat kerjanya yang biasa,kemudahan yang disediakan untuk memenuhi kebutuhannya baik selamadalam perjalanan maupun dilokasi tujuannya. Dari dua pengertian dapat ditarik garis besarnya bahwa pariwisata sebagai suatu aktivitas perjalananke suatu tempat dan tinggal diluar lingkungan mereka untuk sementara waktu.

\section{a. Pemetaan Wisata Kuliner}

Kota Salatiga yang keberadaanya dekat dengan kota Surakarta atau lazim disebut Kota Solo, dan Kota Surakarta adalah bekas kota kerajaan yang kaya akan peninggalan-peninggalan sejarah yang memikat para wisatawan domestik maupun manca negara. Masyarakat Salatiga masih kental dengan pengaruh budaya dari Surakarta baik dari fisik mau non fisik. Surakarta sebagai kota bekas kerajaan Mataram yang kaya akan peninggalanpeninggalan sejarahnya seperti non fisik contohnya adat istiadat, tradisi, kesenian hingga upacara religi dan kalau dikaitkan dengan mesalah kepariwisataan dibedakan menjadi dua yaitu obyek wisata dan atraksi wisata Saeroji dan Wijaya ( 2017). Mengingat Kota Salatiga yang masyarakatnya relative cenderung meniru pola dan budaya masyarakat dari Surakarta, 
kekayaan budaya yang ada saat ini memiliki potensi besar untuk dikembangkan dalam kerangkan kepariwisataan adalah kuliner, kuliner yang sangat beragam di Kota Saltiga belum seluruhnya terakomodasi dan dikemas menjadi sebuah atraksi wisata karena Salatiga yang relative dekat dengan Surakarta juga memiliki beberapa tempat kuliner misalnya Salatiga bagian timur lebih banyak menyediakan kuliner yang masakan jawa dan khas makanan ringan seperti enting-enting gepuk, kerupuk paru, bandeng asap, dendeng, dansebagainya. Sedangkan yang ada didalam kota lebih dominan kuliner makanan khas Salatiga seperti : wedang ronde, bakso, macam-macam soto, dan sebagainya. Sate kambing muda lebih dominan di Kota Salatiga bagian barat dan merupakan jenis makanan yang sudah lama sejak jaman penjajahan sudah dirintis oleh nenek moyangnya hingga saat sekarang ini masih relative eksis dan berkembang .

Fenomena yang menjadi kajian oleh para ahli pariwisata dan para ahli kuliner saat in adalah salah satu ciri produk wisata tidak bisa dipindahkan ke tempat lain namun para wisatawan yang harus datang untuk menikmatinya dan inilah yang dijadikan dasar untuk pengembangan wisata-wisata kuliner pada umumnya Suwantoto dalamSaeroji dan Wijaya (2017). Sate kambing muda di Desa Blotongan Salatiga memiliki kekhasan sendiri karena kambing yang dijadikan sate adalah kambing yang berumur relative masih muda antara enam bulan dan paling tua Sembilan bulan sehingga bisa mendapatkan kualitas daging kambing yang baik dan aroma daging kambing muda yang khas, selanjutnya selain daging kambing yang dibuat sate bisa dibuat masakan seperti Gulai Kambing, Tengkleng, dan Gecok Kambing.

Adapun yang menjadi beberapa catatan dan pertimbangan para wisatawan dalam mengunjungi diarea dan mengunsumsi masakan diwisata kuliner adalah: (1). Harga yang terjangkau (2).Citarasa yang khas (3).Merek (trademark) (4) Kemasan (5) Kualitas makanan (6) Porsi yang sesuai harga (7) Lokasi yang autentik (8) Kualitas bangunan fisik yang khas , (Soleha, 2015) Selanjutnya Suriani dalam Wijaya (2017) untuk mengembangkan wisata kuliner perlu diperhatikan : (1) Inovasi didalam mengembangkan produk sumber daya alam dan sumber daya manusia, (2) Ramah lingkungan 
sosial dan alam, (3) Style atau gaya lokal, (4) Keramahtamahan, (5) Mempertahankan nilai-nilai lokal, (6) Memiliki keautentikan atau kekhasan produk yang tidak dimiliki oleh daerah lain, (7) Tetap menjaga kesederhanaan produk kulinernya.

\section{b. Pengembangan Produk}

Pada dasarnya pengembangan produk sebagai usaha yang dilakukan secara berencana untuk memperbaiki produk yang sedang berjalan atau menambah jenis yang sudah ada. Kotler dalam Soleha (2015) menambahkan bahwa produk sesuatu yang ditawarkan, dimiliki, digunakan, atau dikonsumsi sehingga dapat memuaskan keinginan dan kebutuhan termasuk didalamnya adalah fisik, jasa, orang, tempat, organisasi serta gagasan.Selanjutnya Buchari dalam Ermayani (2003) pengembangan suatu produk bertujuan untuk: Pertama untuk memenuhi konsumen yang belum puas, Kedua, untuk menambah omzet penjualan, Ketiga untuk memenagkan persaingan, Keempat untuk mendayagunakan sumber-sumber produksi, Kelima untuk meningkatkan keuntungan dengan pemakaian bahan yang sama, Keenam untuk mendayagunakan sisa-sisa bahan, Ketujuh untuk mencegah kebosanan konsumen/pelanggan, Kedelapan untuk menyederhanakan produk pembungkus.

Dengan diterimanya proses pengembangan produk oleh konsumen/pelanggan, perusahaan akan mendapatkan dua macam keuntungan yaitu dengan meningkatkan laba karena meningkatnya hasil penjualan dan perusahaan akan efektif jika akan melaksanakan proses pengembangan produkselanjutnya. Dari pengertian tersebut dapat ditarik garis besarnya bahwa pengembangan produk merupakan salah satu faktor atau strategi untuk meningkatkan hasil penjualan, khususnya pengembangan produk wisata kuliner yaitu berupa makanan sate kambing muda yang khas di Desa Blotongan Salatiga.

\section{c. Peningkatan dan Pengembangan Kualitas Makanan}

Kualitas makanan adalah mutu dari makanan itu sendiri, kualitasmakanan sangat dipengaruhi oleh penampilan, rasa, aroma, tekstur, suhu pada saat dihidangkan, warna makanan, dan karakter makanan.Kualitas 
makanan sangat dipengaruhi oleh kepuasan dari pada tamu itu sendiri saat menikmati makanan yang disajikan. Selanjutnya Pauli dalam Soleha (2015) mengatakan kualitas makanan sangat dipengaruhi oleh: Pertama, Presentation yaitu penampilan makanan ang menarik akan membangkitkan selera untuk menikmatinya, Kedua,Taste and flavor yaitu rasa dan aroma makanan itu sendiri yang bisa membuat tamu ingin segera untuk menikmati, Ketiga,Texture yaitu makanan yang baik adalah sesuai dengan jnis makanan itu sendiri, misalnya cara memasak dan bahan makanan bisa mempengaruhi texture makanan. Keempat,Temperature artinya jenis makanan tertentu panas harus dihidangkan dengan cara yang panas, sebaliknya jenis makanan tertentu apa yang harus disajikan pada temperature yang dingin, Kelima,Color of Food yaitu warna makanan yang menarik adalah segar dan alami akan menimbulkan selera makan dibandingkan dengan makanan yang gosong atau berwarna yang pucat, Keenam,Character of Food adalah utntuk membedakan jenis makanan yang satu dengan jenis makanan yang lain, maka setiap makanan selalu memiliki kharakter atau cirri khas tersendiri. Seperti setiap makanan rasa, aroma, warna, hiasan, atau bumbu-bumbu khas pada jenis makanan tertentu tidak sama dengan jenis makanan yang lain, misalnya penyajian kuliner sate kambing muda di Desa Blotongan Salatiga dengan sate kambing muda yang ada di Kota Boyolali berbeda rasadan aromanya, karena tambahan bumbu-bumbu yang berbeda.

\section{d. Dinamika usaha warung makan sate kambing muda Masyhudi}

Almarhum Haji Masjhudi yqang bertempat tinggal di dukuh Prampelan Desa Blotongan atau Jalan Raya Sukarna Hatta Salatiga, almarhum merintis usaha warung makan sate dimulai sejak tahun 1980-an dari waktu kewaktu usahanya biasa-biasa saja. Namun dalam proses perjalamnannya semakinmmaju dan pelanggannya semakin bertambah, mengingat lokasinya di jalan raya Semarang p- Solo yang ramai pemakai jalan dengan sendirinya menambah para pelanggan untuk menikmati masakan sate dari almarhum Masyhudi. Karena bertambahnya pelanggan dari waktu ke waktu usaha warung sate berubah menjadi warung sate kambing muda, sejak tahun 1998 resmi mulai menjajakan warung sate kambing muda dan pelanggannya juga 
semakain bertambah. Sate kambing muda bahan material untuk sate, gulai, tengkleng dan sejenisnya diambil dari kambing yang berumur antara 5 bulan, dan paling tua 7 bulan sehingga rasanya tetap lezat dan tidak keras, hal ini yang semula membedakan para penjual sate lainnya. Disekitarnya di Desa Blotongan ada 14 warung makan sate yang sejak dulu Desa Blotongan terkenal sebagai pusat kuliner sate kambing. Pelanggannya mulai dari Surabaya, Jakarata, Palembang, Aceh, Singapore bahkan Malausia dan Brunaipun juga banyak yang mendatangi sate kambing mudanya almarhum Haji Masyhudi. Sepeninggal Bapak Haji Masyhudi sejak tahun 2006 diteruskan usahanya oleh anaknya yang pertama yaitu saudara Helmy Kurniawan hingga sekarang. Adapun permasalahan yang dihadapi saat ini adalah sulitnya mencari bahan baku kambing muda yang baik, sehat, bebas penyakit dan umurnya kurang dari 7 bulan, setiap hari dibutuhkan paling sedikit 5 ekor kambing muda, sedang untuk hari libur atau weekend dibutuhkan sekitar 8 ekor kambing muda, satu ekor kambing ukuran normal bisa menjadi 400 sunduk sate dan lainnya bisa dijadikan gulai, tengkleng, dan gecok.

\section{METODE PENELITIAN}

Pendekatan penelitian yang relevan digunakan pendekatan deskriptif kualitatif jenis fenomenologis. Dalam rangka peningkatan dan pengembangan ekonomi kreatif sebagai bentuk realisasi keberadaan Undang-Undang Nomor 20 Tahun 2008 tentang UMKM dan Undang-Undang Nomor 10 Tahun2009 tentang Kepariwisataan , serta kebijakan pemerintah tentang pengembangan destinasi wisata di Indonesia. Keterbatasan modal usaha para pelaku usaha wisata kuliner, dan pasangsurutnya para pelaku usaha, serta berlakunya Jalan Toll Sesi Bawen - Salatiga menambah pemahaman fenomena dalam suatu penelitian. Subyek penelitian adalah : Pelaku usaha warung sate kambing muda "Masyhudi”, II,dan III, warung sate kambing muda .yang menempati posisi di jalan raya Solo Semarang, lokasi ada di Desa Blotongan Salatiga. Adapun yang dijadikan informan/nara sumber sebanyak 15 orang informan meliputi : P Helmy sebagai manajer, Ibu Eka Helmy sebagai bendahara, para karyawan di tiga warung sate kambing muda sebanyak 6 orang, dan para pelanggan setia sebanyak 7 orang. Pengumpulan data dilakukan dengan studi dokumentasi, dan 
depth interview (wawancara mendalam) dan observasi untuk mengidentifikasikan secara verbal dan lisan tentang strategi peningkatan dan pengembangan pengelolaan wisata kuliner warung makan guna peningkatan kepuasan pelanggan.

\section{ANALISIS DATA}

Analisis data digunakan model pada tahap mengurai fokus, dalam penelitian dipergunakan alat bantu analisis SWOT untuk mengidentifikasi kekuatan, kelemahan, peluang dan ancaman yang bisa terjadi dalam menggunakan strategi yang dijalankan.Sebagai wujud akuntabilitas dilakukan triangulasi data dengan melakukan member check, silang informan dan jika dipandang perlu dilakukan perpanjangan waktu pengumpulan data sesuai situasi kondisi.

\section{HASIL DAN PEMBAHASAN}

\begin{tabular}{|c|c|c|}
\hline \multicolumn{3}{|c|}{ CONTOH STRATEGIC ANALYSIS AND CHOICE ( SAC ) } \\
\hline $\begin{array}{r}\text { Lingkungan } \\
\text { Internal }\end{array}$ & $\begin{array}{l}\quad \text { Strenght ( S ) } \\
\text { Susunan Daftar } \\
\text { Rangking } \\
\text { 1. Adanya tenaga } \\
\text { trampil } \\
\text { 2.Tempat Strategis } \\
\text { 3. Sudah punya nama }\end{array}$ & $\begin{array}{l}\quad \text { Weakness ( W ) } \\
\text { Susunan Daftar } \\
\text { Rangking } \\
\text { 1. Sulitnya bahan baku } \\
\text { 2. Banyak UKM kuliner } \\
\text { 3. Berlakunya jalan Toll }\end{array}$ \\
\hline $\begin{array}{l}\text { Opportunities ( O ) } \\
\text { Susunan Daftar } \\
\text { Rangking } \\
\text { 1.Pengembangan usaha } \\
\text { 2.Kuliner tdk pernah } \\
\text { mati } \\
\text { 3.Kebijakan pemerintah }\end{array}$ & \begin{tabular}{l}
\multicolumn{1}{c}{ Strategi SO } \\
Susunan Daftar \\
Rangking \\
1. Membuka anak usaha \\
2. Melengkapi prasarana \\
3. Kerjasama adversing
\end{tabular} & $\begin{array}{l}\quad \text { Strategi WO } \\
\text { Susunan Daftar } \\
\text { Rangking } \\
\text { 1.Pelatihan karyawan } \\
\text { 2.Sosialisasi masyrkt } \\
\text { 3.Penguatan wirausaha }\end{array}$ \\
\hline $\begin{array}{l}\quad \text { Threats ( T ) } \\
\text { Susunan Daftar } \\
\text { Rangking } \\
\text { 1. Ketatnya } \\
\text { mompedtitor } \\
\text { 2. Menutunnya } \\
\text { pelanggan } \\
\text { 3. Tidak semua mobil } \\
\text { bisa masuk kota }\end{array}$ & \begin{tabular}{l}
\multicolumn{1}{c}{ Strategi ST } \\
Susunan Daftar \\
Rangking \\
1.Menambah varians \\
baru \\
2.Meningkatkan layanan \\
3.Menjaga kualitas \\
produk
\end{tabular} & $\begin{array}{l}\text { Strategi WT } \\
\text { Susunan Daftar } \\
\text { Rangking } \\
\text { 1.Harga terjangkau } \\
\text { 2.Mempertahankan } \\
\text { selera konsumen } \\
\text { 3.Dijamin halal }\end{array}$ \\
\hline
\end{tabular}


Analisis Masalah 1.

Tabel 1. Perhitungan Faktor Eksternal ( EFAS )

\begin{tabular}{|c|c|c|c|c|c|}
\hline No & $\begin{array}{l}\text { Faktor-faktor Strategi } \\
\text { Eksternal } \\
\text { Peluang ( O ) }\end{array}$ & Bobot & Rating & $\begin{array}{l}\text { Bobot } \\
\text { X } \\
\text { Rating }\end{array}$ & Komentar \\
\hline 1. & $\begin{array}{lr}\text { Peraturan } & \text { Pemerintah } \\
\text { tentang } & \text { pertumbuhan } \\
\text { UMKM } & \end{array}$ & 0,10 & 4 & 0,40 & $\begin{array}{ll}\text { Pengembangan } & \text { usaha } \\
\text { berbasis UMKM dapat } \\
\text { dimanfaatkan } & \text { untuk } \\
\text { menambah modal usaha } & \end{array}$ \\
\hline 2. & $\begin{array}{l}\text { Program Pemerintah } \\
\text { kuliner merupakan bagian } \\
\text { pengembangan wisata }\end{array}$ & 0,15 & 4 & 0,60 & $\begin{array}{l}\text { Peningkatan usaha wisata } \\
\text { kuliner diperlukan fasilitas } \\
\text { yang memadahi guna } \\
\text { meningkatkan kunjungan }\end{array}$ \\
\hline 3. & $\begin{array}{l}\text { Tuntutan masyarakat akan } \\
\text { lapangan kerja }\end{array}$ & 0,15 & 4 & 0,60 & $\begin{array}{lr}\text { Pertumbuhan } & \text { usaha kuliner } \\
\text { bisa } & \text { mengurangi } \\
\text { pengangguran } & \end{array}$ \\
\hline 4. & $\begin{array}{l}\text { Tuntutan tenaga trampil } \\
\text { dibidang kuliner }\end{array}$ & 0,05 & 2 & 0,10 & $\begin{array}{l}\text { Tenaga yang trampil dan } \\
\text { professional dibutuhkan pada } \\
\text { usaha kuliner guna menjaga } \\
\text { keberlanjutan usaha }\end{array}$ \\
\hline 5. & $\begin{array}{l}\text { Kuliner sebagai bentuk } \\
\text { pertumbuhan ekonomi }\end{array}$ & 0,10 & 4 & 0,40 & 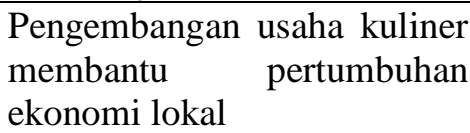 \\
\hline & Jumlah Peluang ( $\mathrm{O}$ ) & 0,55 & & 2,10 & \\
\hline
\end{tabular}

Analisis Masalah 2.

Tabel 2.Perhitungan Faktor Internal ( IFAS )

\begin{tabular}{|c|c|c|c|c|c|}
\hline No & $\begin{array}{l}\begin{array}{l}\text { Faktor-faktor } \\
\text { Internal }\end{array} \\
\text { Kekuatan ( S ) }\end{array}$ & Bobot & Rating & $\begin{array}{l}\text { Bobot } \\
\text { X } \\
\text { Rating } \\
\end{array}$ & Komentar \\
\hline 1. & $\begin{array}{ll}\text { Keberadaan tenaga } \\
\text { terampil }\end{array}$ & 0,15 & 3 & 0,45 & $\begin{array}{ll}\text { Memudahkan } & \text { untuk } \\
\text { berkembangnya usaha } & \end{array}$ \\
\hline 2. & Tempat usaha strategis & 0,40 & 4 & 0,40 & $\begin{array}{l}\text { Memungkinkan usaha lebih } \\
\text { cepat berkembang }\end{array}$ \\
\hline 3. & $\begin{array}{l}\text { Konsumen selalu } \\
\text { memberikan informasi } \\
\text { pada calon konsumen }\end{array}$ & 0,10 & 3 & 0,30 & $\begin{array}{l}\text { Pelanggan selalu bertambah } \\
\text { dari waktu ke waktu }\end{array}$ \\
\hline 4. & $\begin{array}{l}\text { Tenaga senior selalu } \\
\text { melatih yang yunior }\end{array}$ & 0,10 & 3 & 0,30 & $\begin{array}{l}\text { Bertambahnya tempat usaha } \\
\text { akan menambah tenaga } \\
\text { trampil }\end{array}$ \\
\hline 5. & Tumbuhnya ekonomi lokal & 0,15 & 3 & 0,45 & $\begin{array}{l}\text { Mengurangi } \\
\text { pengangguran }\end{array}$ \\
\hline & Jumlah Kekuatan ( S ) & 0,60 & & 1,90 & \\
\hline
\end{tabular}

Dari tabel matrik 1 dan 2, di dapat :

Dari analisis tersebut diatas dapat dilihat bahwa peluang usaha pengembangan wisata kuliner, tuntutan akan lapangan pekerjaan, dan tumbuhnya ekonomi lokal menjadi 
peluang besar untuk pengembangan usaha warung makan sate kambing muda Masyhudi di Desa Blotongan Salatiga. Namun tuntutan akan tenaga yang trampil dan professional menjadi ancaman yang serius.

\section{Analisis Masalah 3.}

Tabel 3. Perhitungan Faktor Internal ( IFAS )

\begin{tabular}{|c|l|l|l|l|l|}
\hline No & $\begin{array}{l}\text { Faktor-faktor Strategi } \\
\text { Internal Bobot }\end{array}$ & Rating & $\begin{array}{l}\text { Bobot } \\
\text { Kelemahan ( W ) } \\
\text { Rating }\end{array}$ & \multicolumn{1}{|l|}{ Komentar } \\
\hline 1. & $\begin{array}{l}\text { Sulitnya bahan baku } \\
\text { kambing muda }\end{array}$ & 0,10 & 2 & 0,20 & $\begin{array}{l}\text { Mendatangkan dari luar } \\
\text { kota/luar provinsi }\end{array}$ \\
\hline 2. & Ketatnya persaingan & 0,05 & 2 & 0,10 & $\begin{array}{l}\text { Menjaga kualitas produk dan } \\
\text { kualitas layanan }\end{array}$ \\
\hline 3. & $\begin{array}{l}\text { Keberadaan jalan Toll } \\
\text { Bawen-Salatiga }\end{array}$ & 0,10 & 2 & 0,20 & $\begin{array}{l}\text { Menata akses kemudahan } \\
\text { mobilitas konsumen }\end{array}$ \\
\hline 4. & $\begin{array}{l}\text { Tenaga terampil sering } \\
\text { diambil pengusaha lain }\end{array}$ & 0,05 & 2 & 0,10 & $\begin{array}{l}\text { Selalu diadakan pelatihan2 } \\
\text { yang terprogram }\end{array}$ \\
\hline 5. & $\begin{array}{l}\text { Mahalnya tenaga yang } \\
\text { profesional }\end{array}$ & 0,10 & 2 & 0,20 & $\begin{array}{l}\text { Merintis adanya tenaga yang } \\
\text { tersertifikasi }\end{array}$ \\
\hline & Jumlah Kelemahan ( W ) & 0,40 & & 0,80 & \\
\hline & Jumlah Total S+W & 1,00 & & 2,70 & \\
\hline
\end{tabular}

Penentuan Posisi Warung Makan Sate Kambing Muda Masyhudi di Desa Blotongan Salatiga dengan menggunakan tabel faktor internal dikurangi faktor ekternal. Posisi warung makan sate kambing muda Masyhudi. Apabila dianalisis dengan diagram Cartesius maka posisi warung makan sate kambing muda dapat dilihat pada perhitungan sebagai berikut:

\begin{tabular}{|l|c|l|c|}
\hline IFAS & & EFAS & \\
\hline Total Skore Kekuatan (S) & 1,90 & Total Skore Peluang (O) & 2,10 \\
\hline Total Skore Kelemahan (W) & 0,80 & Total Skore Ancaman(T) & 1,15 \\
\hline S - W & 1,10 & O - T & 0,95 \\
\hline Absis & 0,55 & Ordinat & 0,45 \\
\hline
\end{tabular}

Kondisi Warung Sate Kambing Muda Masyhudi Di Desa Blotongan Salatiga, Dijelaskan Cortesius SWOT seperti yang ada pada diagram dibawah ini. 


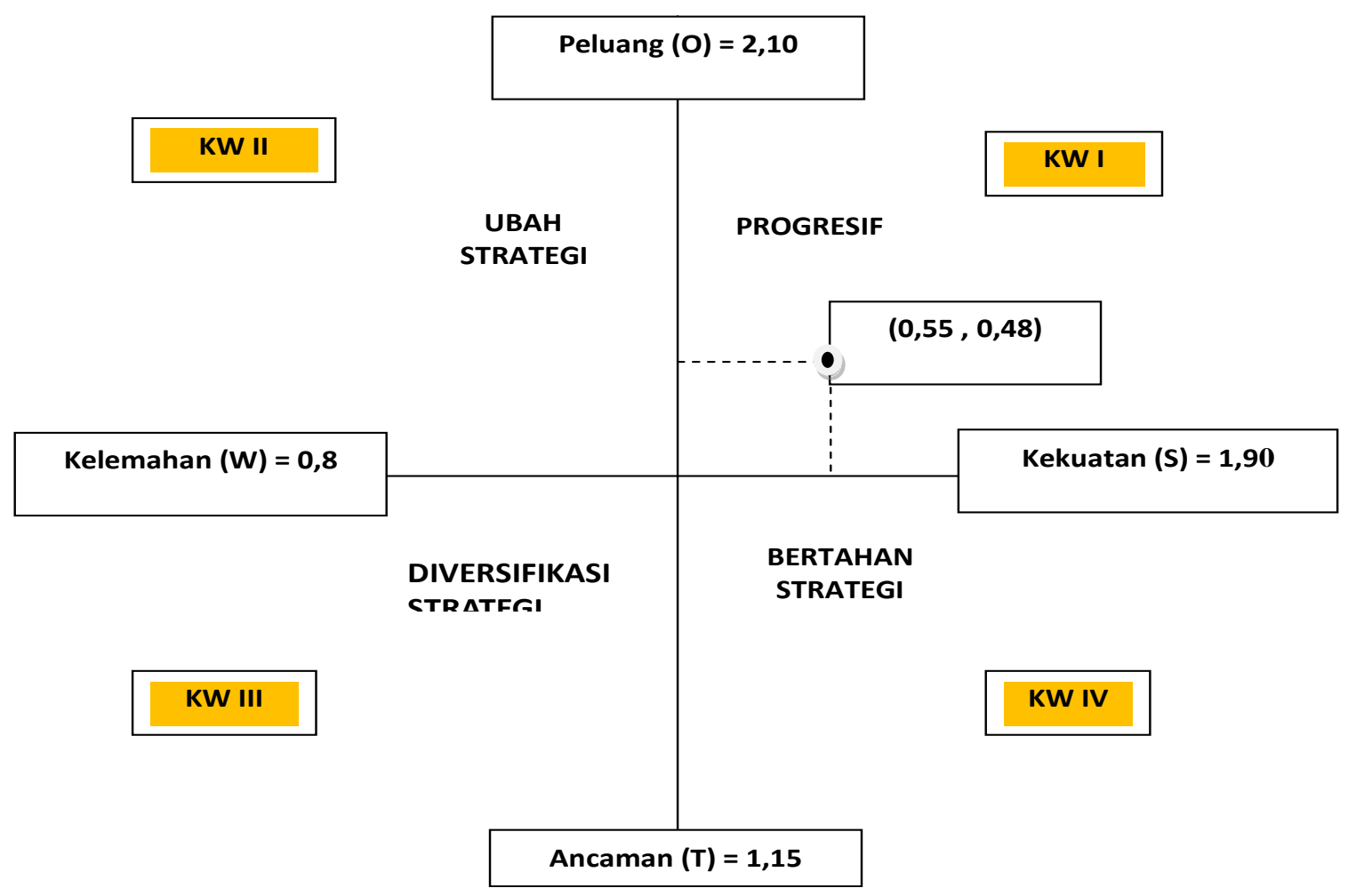

Keterangan dari Cartesius SWOT adalah sebagai berikut :

Posisi warung makan sate kambing muda Masyhudi di Desa Blotongan Salatiga sangat kuat dan berpeluang, Rekomendasi yang diberikan adalah progresif. Artinya kondisi warung makan sate kambing muda Masyhudi dalam kondisi prima dan mantap sehingga sangat dimungkinkan untuk terus dikembangkan usahanya serta membuka beberapa anak usahanya dilain tempat agar bisa mengembangkan jasa kuliner warung makan sate kambing muda agar kedepan bisa lebih maksimal usahanya

\section{KESIMPULAN}

Dari pembahasan dan perhitungan analisis SWOT pada warung makan sate kambing muda Masyhudi di Desa Blotongan diatas dapat disimpulkan:

1. Analisis SWOT adalah didasarkan pada logika yang dapat memaksimalkan kekuatan (Strength), peluang (Opportunities),namun secara bersamaan dapat meminimalkan kelemahan ( Weaknessess), dan ancaman (Treats). Proses pengambilan keputusan strategis selalu berhubungan dengan sikap dan 
perilaku usaha itu sendiri dalam pengembangan visi missi usahanya dalam bidang wisata kuliner warung sate kambing muda yang diberi namaMasyhudi.

2. Analisis SWOT Warung Makan sate kambing muda Masyhudi di Desa Blotongan Salatiga, dilakukan berdasarkan teknik EFAS dan IFAS, yaitu teknik eksternal dan teknik internal kondisi warung makan sate kambing muda Masyhudi di Desa Blotongan, kemudian dihitung dengan perhitungan AFE dan IFE yaitu analisis faktor eksternal dan fakor internal menunjukkan para konsumen merasa puas akan pelayanan yang diberikan oleh warung sate kambing muda Masyhudi.

3. Hasil dari tahap analisis tersebut diperolah hasil sebagai berikut:

Peluang ( O ) : 2,10; Ancaman ( T ) : 1,15; Kekuatan ( S ) : 1,90; Kelemahan (W) : 0,80; Selisish kekuatan dan kelemahan ( S-W ) : 1,10; Selisish Peluang dan Ancaman ( O-T ) : 0,75. Posisi warung makan sate kambing muda Masyhudi di Desa Blotongan Salatiga berdasarkan kortesius SWOT berada di kwadran I, artinya kuat dan berpeluang. Rekomendasinya adalah strategi yang diberikan progresif.Dalam rangka meningkatkan Omzet pendapatan uahanya maka dapat menambah varians atau jenis menu yang disajikan konsumen serta mengembangkan usahanya dengan membuka anak perusahaan.

\section{Saran}

Diharapkan kepada pihak pengusaha wisata kuliner warung sate kambing muda Masyhudi untuk selalu bekerja keras dalam mengimplementasikan stategi peningkatan pelayanan guna pelanggan agar betul-betul mendapat kepuasan. Dengan memanfaatkan peluang-peluang yang ada, terus berinovasi, membangun, memperbaiki diri, menetapkan kebijakan-kebijakan yang baru yang lebih kreatif dan inovatif guna peningkatan kepuasan pelanggan.

Dengan skore analisis jauh diatas poin kelemahan, sehingga kedepan usaha wisata kuliner warung makan sate kambing muda Masyhudi di Desa Blotongan Salatiga semakin mantap dan stabil kondisi usahanya senantiasa terus ditingkatkan kualitas produk dan layanan guna membangun perkembangan usahanya. 


\section{DAFTAR PUSTAKA}

Abas Sunarya, dkk 2014, “ Kewirausahaan " Pnbt : ANDI, Yogyakarta

Amad Saerozi, Deria Adi Wijaya, 2017, Pemetaan Wisata Kuliner Khas Surakarta, Program Studi Diploma Kepariwisataan Sekolah Vokasi UGM, Yogyakarta.

Bayu Etti Tri Adyastiti, 2014, Pengaruh Pembakaran dan Jenis Bahan Bakar Terhadap Kualitas Sensoris dan Kadar Benzoa Piren Sate Kambing. Buletin Fakultas Peternakan Vol 38, (3), UGM

Azwar Saifudin, 2013, "Sikap manusia Teori dan Pengukurannya", Edisi ke-4, Pustaka Pelajar; Yogyakarta

Ermayanti,dkk, 2003, Ensiklopedi Makanan Tradisional di Pulau Jawa dan Pulau Madura, Deputi bidang pelestarian dan Pengembangan Kebudayaan, Jakarta: Proyek Pelestarian dan Pengembangan Kepercayaan.

Kementrian Pariwisata, 2016, Seminar Internasional Tentang Perkembangan Dunia Pariwisata dan Wisata Kuliner Yang Halal, ITB, Bandung.

Kementrian Negara Koperasi dan Usaha Kecildan Menengah Republik Indonesia, 2007 “ Materi Pelatihan : “Diklat Koperasi Bagi Guru” Jakarta

Opi Rachmawati dan Ibnu Widiyanto, 2013,AnalisisPengaruh Keunggulan Produk, Efek Komonitas Terhadap Sikap Merek, dan Implikasinya Terhadap Loyalitas Pelanggan ( Studi Kasus Warung Sate Sapi Pak Kempleng Di Kota Semarang ), Jurnal Manejemen, Undip Vol 2 No.2.

Peraturan Daerah Nomor: 10 Tahun 1993, dan Peraturan Daerah Nomor : 5 Tahun 1996 Tentang “ Tri Fuungsi Kota Salatiga " 2005, Sekretariat Pemda Kota Salatiga.

Peraturan Gubernur Jawa Tengah, Nomor: 41 Tahun 2008, Tentang “ Pemberdayaan Koperasi dan UMKM di Jawa Tengah", 2008, Dinas Koperasi Jawa Tengah, Semarang

Peraturan Pemerintah Nomor: 50 Tahun 2011, Tentang Rencana Induk Pengembangan Kepariwisataan Nasional, Kementrian Pariwisata Indonesia , Jakarta

Saleha, 2015, Pengembangan Makanan Tradisional Lumpia Sebagai Produk Wisata Kuliner Di Kota Semarang, Tesis PPs STIEPARI, Semarang

Samtono, 2009, Dinamika sikap dan Perilaku Guru-Guru SMA Kota Salatiga dalam melaksanakan Kurikulum Berbasisi Kompetensi ( KBK ), Desertasi Program Doktor Studi Pembangunan Pascasarjana, UKSW Salatiga.

Undang-Undang Republik Indonesia Nomor 20 Tahun 2008, Tentang “Usaha Mikro, Kecil dan Menengah" 2008, Lembaran Negara RI Nomor: 4866, Jakarta. 